February 2001 - NREL/CP-550-29694

\title{
Ground-Coupled Heat and Moisture Transfer from Buildings Part 2: Application
}

\section{Preprint}

\section{M.P. Deru}

National Renewable Energy Laboratory
A.T. Kirkpatrick
Colorado State University

To be presented at the American Solar Energy Society (ASES) National Solar Conferences Forum 2001 Washington, D.C.

April 21-25, 2001

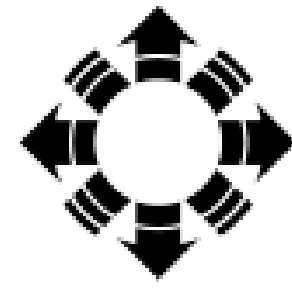

\section{NPEI}

National Renewable Energy Laboratory

1617 Cole Boulevard

Golden, Colorado 80401-3393

NREL is a U.S. Department of Energy Laboratory

Operated by Midwest Research Institute $\bullet$ Battelle $\bullet$ Bechtel

Contract No. DE-AC36-99-G010337 


\section{NOTICE}

The submitted manuscript has been offered by an employee of the Midwest Research Institute (MRI), a contractor of the US Government under Contract No. DE-AC36-99G010337. Accordingly, the US Government and MRI retain a nonexclusive royalty-free license to publish or reproduce the published form of this contribution, or allow others to do so, for US Government purposes.

This report was prepared as an account of work sponsored by an agency of the United States government. Neither the United States government nor any agency thereof, nor any of their employees, makes any warranty, express or implied, or assumes any legal liability or responsibility for the accuracy, completeness, or usefulness of any information, apparatus, product, or process disclosed, or represents that its use would not infringe privately owned rights. Reference herein to any specific commercial product, process, or service by trade name, trademark, manufacturer, or otherwise does not necessarily constitute or imply its endorsement, recommendation, or favoring by the United States government or any agency thereof. The views and opinions of authors expressed herein do not necessarily state or reflect those of the United States government or any agency thereof.

Available electronically at http://www.doe.gov/bridge

Available for a processing fee to U.S. Department of Energy and its contractors, in paper, from:

U.S. Department of Energy

Office of Scientific and Technical Information

P.O. Box 62

Oak Ridge, TN 37831-0062

phone: 865.576 .8401

fax: 865.576.5728

email: reports@adonis.osti.gov

Available for sale to the public, in paper, from:

U.S. Department of Commerce

National Technical Information Service

5285 Port Royal Road

Springfield, VA 22161

phone: 800.553 .6847

fax: 703.605.6900

email: orders@ntis.fedworld.gov

online ordering: http://www.ntis.gov/ordering.htm

Printed on paper containing at least $50 \%$ wastepaper, including $20 \%$ postconsumer waste 


\section{Ground-Coupled Heat and Moisture Transfer From Buildings Part 2 - Application}

\author{
Michael P. Deru \\ National Renewable Energy Laboratory \\ 1617 Cole Boulevard \\ Golden CO 80401 \\ 303-384-7503 michael_deru@nrel.gov
}

\author{
Allan T. Kirkpatrick \\ Mechanical Engineering Department \\ Colorado State University \\ Fort Collins CO 80523 \\ 970-491-5500 allan@engr.colostate.edu
}

\begin{abstract}
In this paper the effects of moisture on the heat transfer from two basic types of building foundations, a slab-on-grade and a basement, are examined. A twodimensional finite element heat and moisture transfer program is used to show the effects of precipitation, soil type, foundation insulation, water table depth, and freezing on the heat transfer from the building foundation. Comparisons are made with a simple heat conduction model to illustrate the dependency of the soil thermal conductivity on moisture content.
\end{abstract}

\section{NOMENCLATURE}

$$
\begin{aligned}
\mathrm{G} & =\text { global horizontal solar radiation }\left[\mathrm{Wh} / \mathrm{m}^{2}\right] \\
\mathrm{k} & =\text { thermal conductivity }[\mathrm{W} / \mathrm{m} \mathrm{K}] \\
\mathrm{T} & =\text { temperature }\left[{ }^{\circ} \mathrm{C}\right] \\
\mathrm{t} & =\text { time }[\mathrm{h}] \\
\mathrm{u} & =\text { wind speed }[\mathrm{m} / \mathrm{s}]
\end{aligned}
$$

\section{Subscripts}

$$
\mathrm{a}=\text { amplitude }
$$$$
\mathrm{m}=\text { mean }
$$

\section{Introduction}

A well-built house today is so energy efficient above ground that the ground-coupled heat losses are a significant fraction of the total heat loss. For most buildings, the earth acts as a heat sink continually conducting heat from the building foundation. The conduction heat transfer through the soil is governed by the soil thermal conductivity, which in turn depends primarily on three parameters: the soil type, the amount of moisture in the soil, and the soil temperature. The objectives of this paper are twofold: 1) to study how the foundation heat transfer varies with soil type, seasonal atmospheric conditions, insulation level, and ground water depth; and 2) to determine how well a heat conduction model can account for soil property variations resulting from soil moisture changes. The two basic types of building foundations, a slab-on-grade and a basement, are examined. A soil heat and mass transfer model developed in a previous paper $[1,2]$ is used to compute the soil temperature and moisture profiles, the soil thermal conductivity, and the resulting heat transfer from building foundations.
Ground coupled heat transfer from building foundations has been the subject of many analytical, numerical and experimental investigations. Ground heat transfer modeling has usually assumed a given value of the soil thermal conductivity, constant soil properties, a simplified treatment of the surface energy balance, and has not included precipitation or ground water table considerations. The first well-known analytical transient solution was developed by Lachenbruch [3] who solved the heat conduction equation using Green's functions, assuming uniform and constant thermal properties. Muncey and Spencer [4], Shen and Ramsey [5], Delsante and Stokes [6], and Claesson and Hagentoft [7] developed analytical procedures to predict heat loss from slab-on-grade floors. Krarti, et al. Used a combined numerical and analytical approache to solve the heat conduction problem [8-10]. Mitalas [11, 12] developed basement heat loss factors from hundreds of numerical simulations of the heat loss from slab floors, shallow basements, and deep basements. Mitalas noted that the heat loss can be significantly affected by ground water, changes in soil thermal conductivity due to moisture and temperature, and variations in ground surface conditions. Shen $[13,14]$ was the only researcher to perform detailed simulations of coupled heat and moisture transfer. Shen noted that there was a small increase in the predicted heat loss from a basement wall when moisture transfer was considered. Bahnfleth $[15,16]$ developed a detailed three-dimensional finite difference model for heat conduction from slab-on-grade floors and basements, including a detailed ground surface energy balance. By comparing experimental and numerical results, Adjali, et al. [17] concluded that neglecting the effects of precipitation could significantly affect the predicted ground temperature distribution.

\section{Computational Configurations and Parameters}

Computations were performed using the twodimensional finite element heat and mass transfer model developed in $[1,2]$. The parameters studied were: precipitation onto the soil surface, the weather season, the foundation insulation level, the type of soil, and ground water depth. Computations were performed with and without precipitation, with summer and winter conditions, 
with and without insulation, and with Bighorn sandy loam or Yolo light clay [18]. The hydraulic and thermal properties of these two soils are given in [2].

Two general geometries were used in the computations: a half width slab-on-grade floor and a half width basement. Figures 1 and 2 show the geometries and the boundary conditions used for the two problems. Note that the slab floor and basement wall were also included in the FEM mesh. The boundary conditions along the sides were zero heat and moisture fluxes. The bottom boundary, representing a ground water table depth of $10 \mathrm{~m}$, was maintained at a matric potential $\psi=0.0 \mathrm{~m}$ (i.e. saturated soil) and $\mathrm{T}=10{ }^{\circ} \mathrm{C}$. The air temperature above the floor was fixed at $20{ }^{\circ} \mathrm{C}$ with the convective heat transfer coefficients for the floor equal to $6.0 \mathrm{~W} / \mathrm{m}^{2} \mathrm{~K}$ and 8.3 $\mathrm{W} / \mathrm{m}^{2} \mathrm{~K}$ for the basement wall. The ground surface boundary was assumed to have vegetation height of $10 \mathrm{~cm}$, a long wave emittance of 0.9 , and a reflectance of 0.23 . Grid and time step size considerations for these geometries are discussed by Deru [2]. The concrete, gravel, and insulation material properties used in the simulations are shown in Table 1. The insulated cases included $5 \mathrm{~cm}$ of insulation under the entire floor and along the outside of the foundation wall and $2 \mathrm{~cm}$ of insulation separating the floor from the foundation or basement wall. Moisture transport within the gravel under the slab was neglected. The thermal conductivity of the soil is calculated as a function of soil type, moisture content, and temperature.

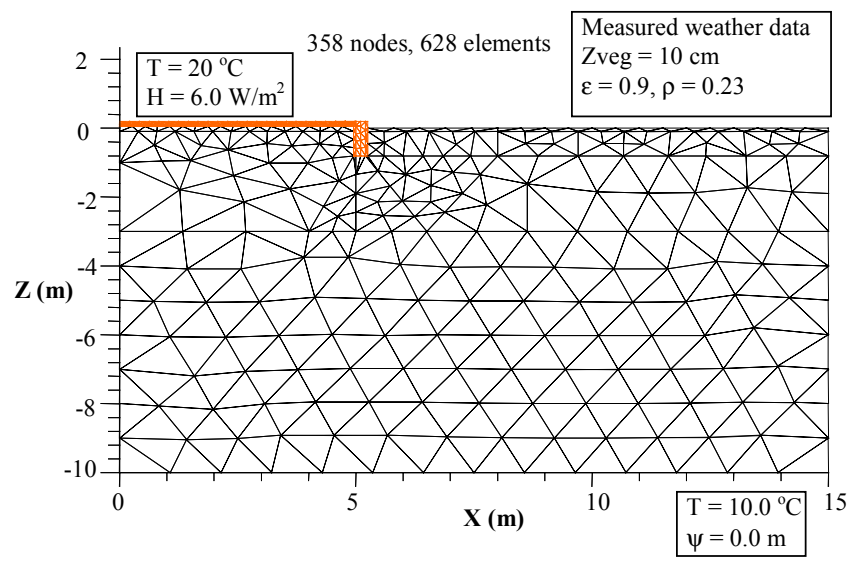

Figure 1. Mesh and boundary conditions used for the slab-on-grade simulations.

The initial temperature and moisture conditions for the summer simulations were obtained by starting with linear temperature and moisture distributions in the vertical dimension and calculating the soil conditions for a three year period with sinusoidal varying weather conditions and precipitation of $25 \mathrm{~mm}$ added once a week to keep the surface from becoming completely dry. The initial conditions for the winter simulations started with the results at the end of the three-year summer run and ran for one more year with the winter-1 conditions from Table 2.

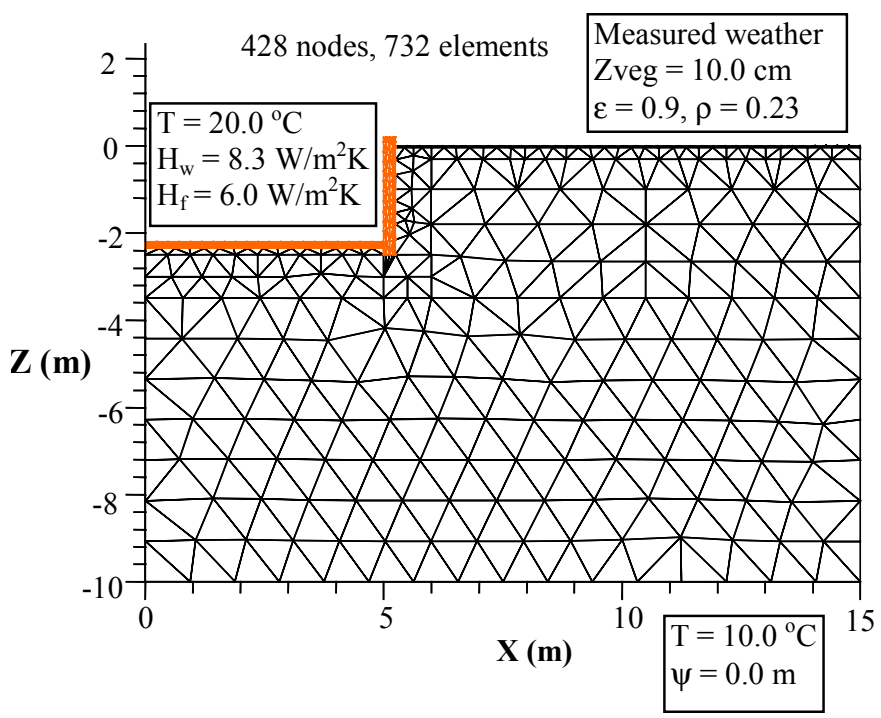

Figure 2. Mesh and boundary conditions used for the basement simulations.

Table 1. Material properties used for ground heat transfer simulations.

\begin{tabular}{|l|c|c|c|c|}
\hline \multicolumn{1}{|c|}{ material } & $\begin{array}{c}\text { thick } \\
(\mathrm{cm})\end{array}$ & $\begin{array}{c}\boldsymbol{\rho} \\
\left(\mathrm{kg} / \mathrm{m}^{3}\right)\end{array}$ & $\begin{array}{c}\mathbf{k} \\
(\mathrm{W} / \mathrm{m} \mathrm{K})\end{array}$ & $\begin{array}{c}\mathbf{C}_{\mathbf{p}} \\
(\mathrm{J} / \mathrm{kg} \mathrm{K})\end{array}$ \\
\hline \hline concrete floor & 10 & 2400 & 1.5 & 1000 \\
\hline concrete wall & 20 & 2400 & 1.5 & 1000 \\
\hline gravel & 15 & 2000 & 2.0 & 812 \\
\hline insulation & 5 & 40 & 0.029 & 1.21 \\
\hline
\end{tabular}

The daily atmospheric conditions used in the computations are given by Eq.'s (1), (2), and (3) for the solar radiation, temperature and wind speed. The coefficients for the weather equations are given in Table 2. Three seasonal weather conditions were modeled: summer, Winter-1, and Winter-2. The two winter conditions are progressively colder, with decreased solar radiation. The solar radiation was set to zero if the values from Eq. (1) were negative.

$$
\begin{aligned}
& \mathrm{G}=\mathrm{G}_{\mathrm{m}}+\mathrm{G}_{\mathrm{a}} \sin (\pi(2 \mathrm{t} / 24-1 / 2)) \\
& \mathrm{T}=\mathrm{T}_{\mathrm{m}}+\mathrm{T}_{\mathrm{a}} \sin (\pi(2 \mathrm{t} / 24-2 / 3)) \\
& \mathrm{u}=\mathrm{u}_{\mathrm{m}}+\mathrm{u}_{\mathrm{a}} \sin (\pi(6 \mathrm{t} / 24-1 / 2))
\end{aligned}
$$


Table 2. Weather parameters used for ground heat transfer simulations.

\begin{tabular}{|l|l|r|r|r|}
\hline \multicolumn{1}{|c|}{ Variable } & \multicolumn{1}{c|}{ units } & Summer & Winter- 1 & Winter- 2 \\
\hline \hline $\mathrm{G}_{\mathrm{m}}$ & $\mathrm{Wh} / \mathrm{m}^{2}$ & 0.0 & 0.0 & 0.0 \\
\hline $\mathrm{G}_{\mathrm{a}}$ & $\mathrm{Wh} / \mathrm{m}^{2}$ & 900.0 & 450.0 & 200.0 \\
\hline $\mathrm{T}_{\text {drybulb-m }}$ & ${ }^{\circ} \mathrm{C}$ & 15 & 0.0 & -10.0 \\
\hline $\mathrm{T}_{\text {drybulb-a }}$ & ${ }^{\circ} \mathrm{C}$ & 10 & 5.0 & 5.0 \\
\hline $\mathrm{T}_{\text {dewpoint-m }}$ & ${ }^{\circ} \mathrm{C}$ & 7.5 & -1.0 & -12.0 \\
\hline $\mathrm{T}_{\text {dewpoint-a }}$ & ${ }^{\circ} \mathrm{C}$ & 5.0 & 4.0 & 4.0 \\
\hline $\mathrm{u}_{\mathrm{m}}$ & $\mathrm{m} / \mathrm{s}$ & 4.0 & 4.0 & 4.0 \\
\hline $\mathrm{u}_{\mathrm{a}}$ & $\mathrm{m} / \mathrm{s}$ & 2.0 & 2.0 & 2.0 \\
\hline precip & $\mathrm{mm}$ & 25.0 & 25.0 & 25.0 \\
(slab/base) & & 50.0 & & 50.0 \\
\hline
\end{tabular}

The Winter- 1 weather parameters in Table 2 were used during the one-year set up run for the initial conditions, the Winter-2 values were used with the slab-on-grade and basement simulations. All of the summer simulations were 16 weeks (112 days) and the winter simulations were 8 weeks (56 days) in extent.

\section{Results}

3.1. Effect of Soil Type, Precipitation, and Insulation on Slab-on-Grade Heat Transfer

The fourteen slab-on-grade simulation cases are listed in Table 3. For the rainy cases, $25 \mathrm{~mm}$ of precipitation was added on days 7 and 14 during hour 7 a.m. The simulation parameters are summarized by a five-letter code: S (Slab), summer (s) or winter(w), rain(r) or dry(d), full(f) or no(n) insulation, and sandy loam(s) or clay(c) soil type. For example, as indicated in Table 3, Ssrns represents a slab-ongrade with summer, rain, no insulation, and sandy loam soil.

Table 3. Slab-on-grade simulation cases

\begin{tabular}{|c|l|l|}
\hline Case & Code & \multicolumn{1}{|c|}{ Description } \\
\hline \hline 1 & Ssrfs & slab, summer, rain, full insulation, sand \\
\hline 2 & Ssdfs & slab, summer, dry, full insulation, sand \\
\hline 3 & Ssrns & slab, summer, rain, no insulation, sand \\
\hline 4 & Ssdns & slab, summer, dry, no insulation, sand \\
\hline 5 & Ssrfc & slab, summer, rain, full insulation, clay \\
\hline 6 & Ssdfc & slab, summer, dry, full insulation, clay \\
\hline 7 & Ssrnc & slab, summer, rain, no insulation, clay \\
\hline 8 & Ssdnc & slab, summer, dry, no insulation, clay \\
\hline 9 & Swrfs & slab, winter, rain, full insulation, sand \\
\hline 10 & Swdfs & slab, winter, dry, full insulation, sand \\
\hline 11 & Swrns & slab, winter, rain, no insulation, sand \\
\hline 12 & Swdns & slab, winter, dry, no insulation, sand \\
\hline 13 & Swrnc & slab, winter, rain, no insulation, clay \\
\hline 14 & Swdnc & slab, winter, dry, no insulation, clay \\
\hline
\end{tabular}

The spatial heat flux profiles across the slab-on-grade floor at 12:00 p.m. on day 14 of Winter-2 for three cases: dry-no-insulation, rain-no-insulation, and rain-insulation, all with sandy loam soil are shown in Fig. 3. As expected, the effect of the insulation is substantial for the first two meters in from the outside edge. At the center of the floor, the insulation still reduces the heat loss by over one third. The addition of rain has a very small effect on the heat loss from the slab for the winter weather conditions.

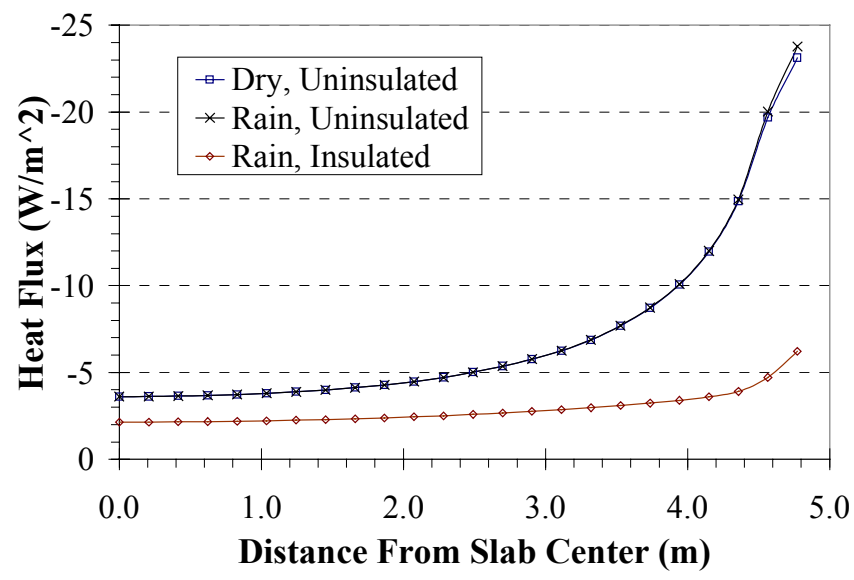

Figure 3. Heat flux across the slab-on-grade floor at 12:00 on day 14 with sandy loam soil and winter conditions.

The hourly heat loss per unit depth from the slab for the Summer cases are shown in Fig. 4 for the insulation cases and in Fig. 5 for the uninsulated cases. All 112 days are plotted in Fig. 4 and the first 35 days are plotted in Fig. 5. The heat loss for the Sandy loam soil is greater than that for the clay soil. The addition of rain on days 7 and 14 has an obvious effect on the heat transfer from the slab for all cases. The effect of the rain on the insulated floors is smaller, but lasts longer than the uninsulated floors. The general downward slope of the graphs is due to the surface soil slowly drying out, which lowers the soil thermal conductivity.

The average magnitude of the heat transfer from the uninsulated slab is about twice the value from the insulated slab. The increase in heat loss due to the addition of precipitation was the following: $1.2 \%$ for the insulated sandy loam, $3.1 \%$ for the uninsulated sandy loam, $0.4 \%$ for the insulated Yolo light clay, and $1.2 \%$ for the uninsulated Yolo light clay. 


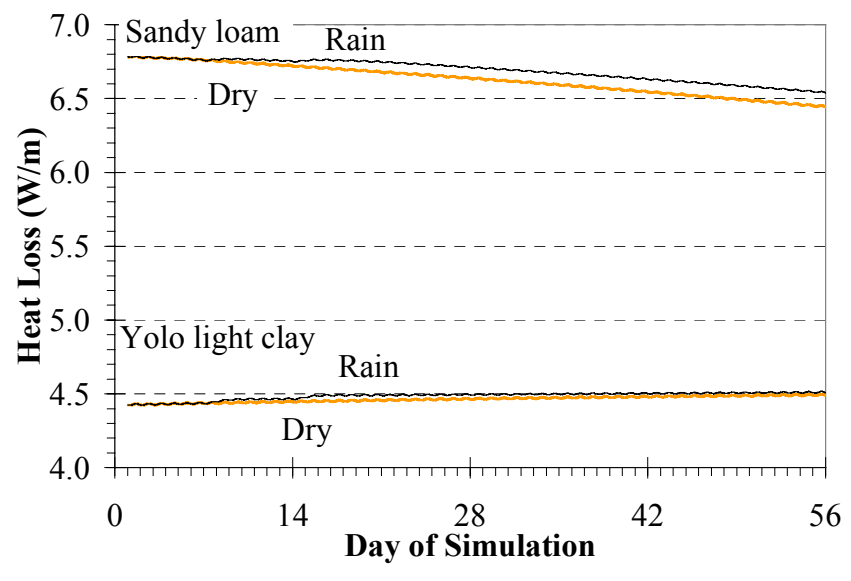

Figure 4. Hourly slab floor heat loss for the summer insulated cases with $25 \mathrm{~mm}$ of rain on days 7 and 14 .

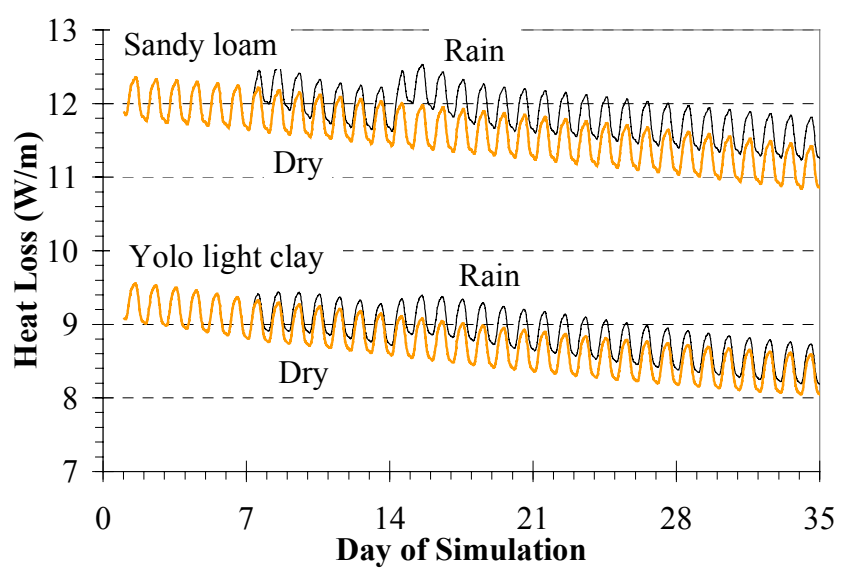

Figure 5. Hourly slab floor heat loss for the summer uninsulated cases with $25 \mathrm{~mm}$ of rain on days 7 and 14 .

\subsection{Effect of Precipitation and Insulation on Basement Heat Transfer}

The eight basement cases studied are listed in Table 4 . For the rainy cases, $50 \mathrm{~mm}$ of precipitation was added on day 7 of the simulations. The simulation parameters are summarized by a five letter code: B (basement), summer (s) or $\operatorname{winter}(\mathrm{w})$, rain(r) or $\operatorname{dry}(\mathrm{d})$, full(f) or no(n) insulation, and sandy loam(s) or clay(c) soil type. For example, as indicated in Table 4, Bsrns represents a basement with summer, rain, no insulation, and sandy loam soil.

The daily heat losses from the basement wall for the four summer cases are plotted in Fig. 6. The uninsulated case shows a larger jump in heat loss when rain is included. The total heat loss over the 112 days from the basement wall increases by $5.7 \%$ and $6.4 \%$ for the insulated and uninsulated walls when precipitation is added to the ground surface. Since the basement floor is about two meters below the ground, it is relatively unaffected by the addition of rain to the ground surface. The general decrease in the heat loss during the summer is due to the drying of the soil. The insulation has a large effect, reducing the heat loss by almost $49 \%$ in both the rainy and dry cases.

There was no noticeable change in the total heat loss for the winter cases when rain was added for both the insulated and uninsulated basements. The ratio of the heat loss from the floor and the walls changes with the weather conditions. In the summer, approximately $70 \%$ of the heat loss was from the floor, but in the winter it is only about $30 \%$ of the total. The insulation on the basement wall is very effective in the winter cases, reducing the wall heat losses by over $70 \%$.

Table 4. Cases to show effects of surface moisture on ground-coupled heat transfer from basements.

\begin{tabular}{|c|c|l|}
\hline Case & Code & \multicolumn{1}{c|}{ Description } \\
\hline \hline 1 & Bsrfs & basement, summer, rain, full insulation, sand \\
\hline 2 & Bsdfs & basement, summer, dry, full insulation, sand \\
\hline 3 & Bsrns & basement, summer, rain, no insulation, sand \\
\hline 4 & Bsdns & basement, summer, dry, no insulation, sand \\
\hline 5 & Bwrfs & basement, winter, rain, full insulation, sand \\
\hline 6 & Bwdfs & basement, winter, dry, full insulation, sand \\
\hline 7 & Bwrns & basement, winter, rain, no insulation, sand \\
\hline 8 & Bwdns & basement, winter, dry, no insulation, sand \\
\hline
\end{tabular}

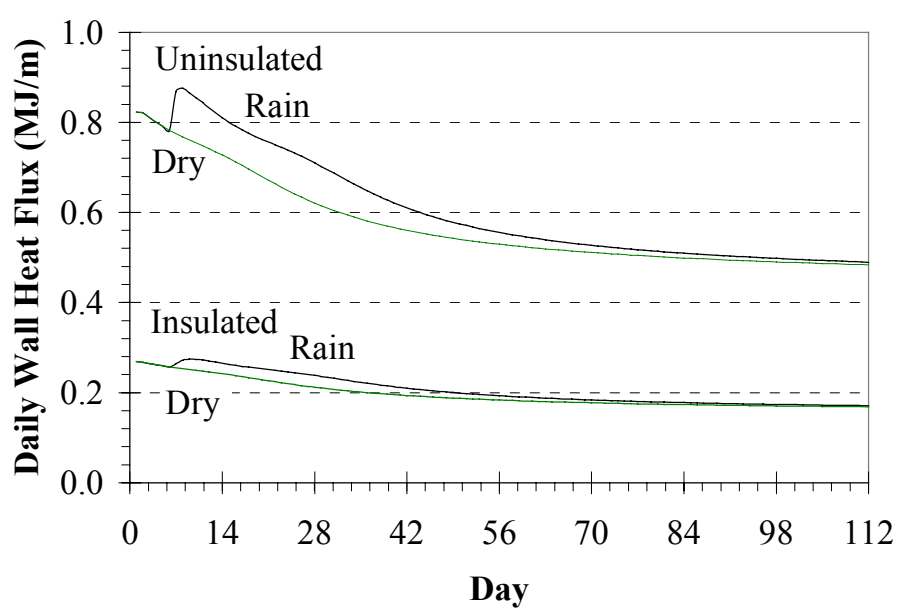

Figure 6. Daily basement wall heat loss for the summer cases with $50 \mathrm{~mm}$ of rain on day 7.

\subsection{Effect of Freezing on Heat Transfer From a Basement}

To determine the effect of the freezing phase change on the heat transfer from a basement, the winter case with no insulation and a $5 \mathrm{~m}$ water table depth was run with the ground freezing model turned off in the heat and mass transfer computations. There was no change in the heat loss from the floor and only a $2.8 \%$ increase in the heat loss from the wall over the 56 days of the simulation. This result suggests that the effect of soil freezing is small, provided that the frozen soil thermal conductivity can be properly modeled. 


\subsection{Effect of Ground Water Depth on Heat Transfer From} a Basement

Ground water is usually modeled as a constant temperature boundary, which is a limitation of the heat conduction only models. With a heat and moisture transfer model, the ground water can be modeled as a saturated boundary. This is significant because it provides a moisture source for the soil, which increases the soil thermal conductivity. To show the effects of ground water depth on the heat transfer from the basement configuration, the water table was simulated at depths of $10 \mathrm{~m}, 5 \mathrm{~m}$, and $3 \mathrm{~m}$. With the water table at a $5 \mathrm{~m}$ depth, the summer temperature of the water table was assumed to be $10{ }^{\circ} \mathrm{C}$ and the winter temperature assumed to be $7{ }^{\circ} \mathrm{C}$. For the case with a water table at $3 \mathrm{~m}$, the summer and winter water table temperatures were $10{ }^{\circ} \mathrm{C}$ and $5{ }^{\circ} \mathrm{C}$.

Figure 7 shows the average daily heat losses using the Winter-2 conditions for the three different water table depths. The water table depth has the largest impact on the floor heat losses, especially for the uninsulated cases. The wall heat losses for the uninsulated cases are much higher than the insulated cases. The increases in the total heat loss from the $10 \mathrm{~m}$ depth to the $5 \mathrm{~m}$ depth are $126 \%$ and $133 \%$ for the insulated and uninsulated cases and 169\% and 239\% for the insulated and uninsulated cases going from $10 \mathrm{~m}$ to 3 $\mathrm{m}$. The magnitude of the heat transfer increase is not unexpected, as there are two effects that cause the increase in heat loss. Firstly, the temperature gradient in the soil from the floor to the water table is increased since the water table is closer to the floor, and secondly, the soil moisture content and thermal conductivity are also increased in the region between the floor and the water table.

\subsection{Comparison of the Heat and Moisture Transfer Model with a Heat Transfer Model}

We now turn to the problem of determining what value of thermal conductivity to use with a ground heat transfer only computation. In this paper we have used an iterative method. We assume a value of thermal conductivity, compute the heat loss using a heat conduction model, and compare the results with the heat and mass transfer model of [1]. Annual simulations using hourly weather data were performed with sandy clay loam [1] and the basement geometry shown in Fig. 2, with the lower boundary set at $z=-5.0 \mathrm{~m}$. The ground surface had a vegetation height of $z_{\mathrm{veg}}=10 \mathrm{~cm}$, infrared emissivity of $\varepsilon=0.9$, and a reflectivity of $\rho=0.23$.

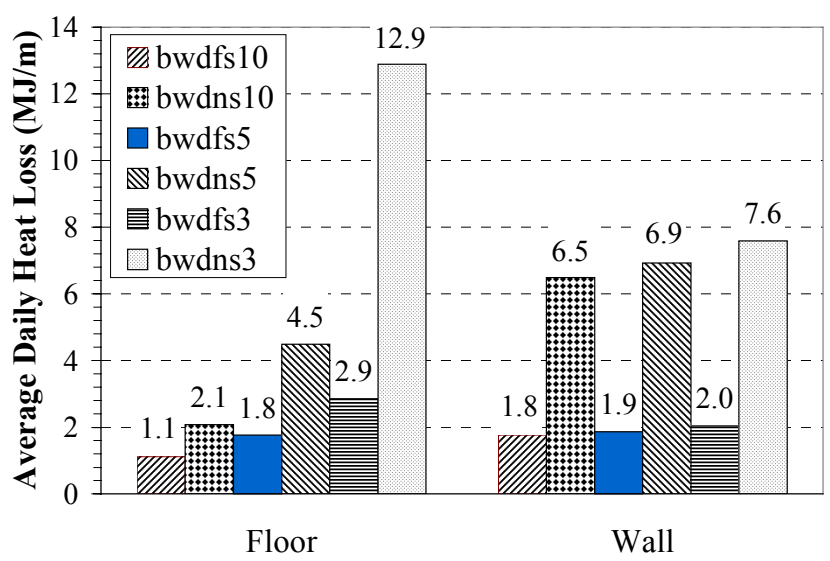

Figure 7. Average daily basement heat losses for winter insulated and uninsulated cases with ground water depths of $10 \mathrm{~m}, 5 \mathrm{~m}$ and $3 \mathrm{~m}$.

The hourly weather data (temperature, solar radiation, humidity, precipitation) were measured in 1999 in Fort Collins, Colorado. Cloud cover information is not included in this data set, therefore, opaque cloud cover was only modeled during hours with precipitation then tapering off for two hours after the rain ended. Insulation with $\mathrm{R}=1.724 \mathrm{~m}^{2} \mathrm{~K} / \mathrm{W}$ was added to the outside of the basement wall extending $1.2 \mathrm{~m}$ down from the top. The boundary conditions for the bottom boundary were a constant temperature, $\mathrm{T}=10{ }^{\circ} \mathrm{C}$, and saturated soil, $\psi=0.0 \mathrm{~m}$. The indoor conditions were a constant temperature, $\mathrm{T}=20{ }^{\circ} \mathrm{C}$, with a convective heat transfer coefficient of $\mathrm{h}=6.0 \mathrm{~W} / \mathrm{m}^{2} \mathrm{~K}$ for the floor and $\mathrm{h}=8.3 \mathrm{~W} / \mathrm{m}^{2} \mathrm{~K}$ for the wall. The boundaries along the sides of the domain were modeled as non-porous adiabatic surfaces. To obtain the initial conditions, the models were run for one year starting with the temperature and moisture distributions from the winter cases run in the previous section.

The annual results from the two models are listed in Table 5. Two simulations were completed with the heat conduction model using soil thermal conductivities of $1.75 \mathrm{~W} / \mathrm{m} \cdot \mathrm{K}$ and $2.03 \mathrm{~W} / \mathrm{m} \cdot \mathrm{K}$ The first value is the thermal conductivity of the soil at the critical moisture content $\theta_{\mathrm{k}}=0.09$, which is approximately the wilting point of this soil and is the value at the knee in the thermal conductivity vs. moisture curve. The second value of thermal conductivity was estimated by comparing the results from $\mathrm{k}=1.75 \mathrm{~W} / \mathrm{m} \cdot \mathrm{K}$ with the results from the heat and moisture transfer model. 
Assuming that the heat and moisture transfer model provides the benchmark value, a rough estimate of the thermal conductivity can be calculated from:

$$
\begin{aligned}
k_{2} & =\frac{Q_{2}}{Q_{1}} k_{1} \\
& =\frac{1730}{1493} 1.75 \\
& =2.03
\end{aligned}
$$

Table 5. Annual half basement heat loss values (per unit length of perimeter).

\begin{tabular}{|l|l|l|l|c|}
\hline & \multicolumn{4}{|c|}{ Annual Heat Loss (MJ/m) } \\
\hline & Floor & Wall & Total & Delta (\%) \\
\hline \hline Heat and Moisture & 1203.4 & 526.7 & 1730.0 & $\mathrm{n} / \mathrm{a}$ \\
\hline Heat $(\mathrm{k}=1.75)$ & 1045.1 & 448.2 & 1493.3 & -13.7 \\
\hline Heat $(\mathrm{k}=2.03)$ & 1174.8 & 484.0 & 1658.8 & -4.1 \\
\hline
\end{tabular}

The annual energy loss using a heat transfer model with a soil thermal conductivity of $\mathrm{k}=1.75 \mathrm{~W} / \mathrm{m} \cdot \mathrm{K}$ is much lower than the energy loss predicted by the heat and mass transfer model. The results with $\mathrm{k}=2.03$ $\mathrm{W} / \mathrm{m} \cdot \mathrm{K}$ are better, especially the floor heat losses, in which the two models differ by only $2.4 \%$.

Two additional cases were completed: the first had a thermal conductivity of $2.03 \mathrm{~W} / \mathrm{m} \cdot \mathrm{K}$ for the soil from the surface to the depth of the basement floor and the soil below the floor had $\mathrm{k}=2.05 \mathrm{~W} / \mathrm{m} \cdot \mathrm{K}$, the second case used seasonal values of thermal conductivity with the winter value $\mathrm{k}_{\text {win }}=2.03 \mathrm{~W} / \mathrm{m} \cdot \mathrm{K}$ and the summer value $\mathrm{k}_{\text {sum }}=2.2 \mathrm{~W} / \mathrm{m} \cdot \mathrm{K}$. The first case was used to simulate the higher moisture content in the deep soil and the second was to simulate a common practice of using a seasonal value of thermal conductivity. The case with thermal conductivity varying with depth improved the results slightly to $-4.0 \%$ difference between the two models. The simulation with seasonal thermal conductivity was only $2.0 \%$ less; however, the floor heat loss was under predicted in the winter and over predicted in the summer with large jumps corresponding to the changes in the soil thermal conductivity. It is recommended that seasonal values of soil thermal conductivity only be used with caution.

To examine the seasonal variations in the heat loss, the total daily heat loss for the first three cases are graphed in Fig. 8. From a qualitative point of view, the two models exhibit a similar behavior for the total daily heat loss. The winter and early spring results are almost identical; however, the results for the summer and fall diverge slightly. Most of the difference comes from the wall heat loss, which does not change as much as the floor heat loss with the increased thermal conductivity. Some of this is due to the detailed simulation of the surface evaporation in the heat and moisture transfer model, which provides a cooler surface temperature and higher heat transfer rates. This shows that a heat conduction model can perform reasonable well on an annual basis with the correct value of soil thermal conductivity, but care should be taken when looking at seasonal variations.

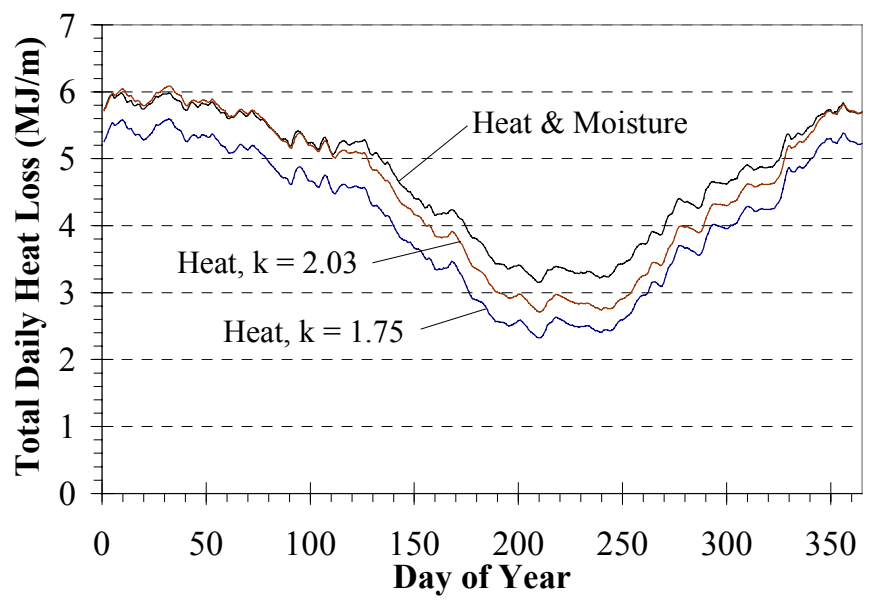

Figure 8. Daily total basement heat loss values predicted by the heat and moisture transfer model and the heat transfer model with two soil thermal conductivities.

\section{Summary and Conclusions}

In this paper the effects of precipitation and water table depth on heat transfer from building foundations was investigated using a heat and mass transfer model. The thermal conductivity of soils around buildings depends on the moisture level of the soil. It was found that the effect of precipitation was largest for uninsulated foundation slabs during summer weather conditions. The heat transfer from walls of basements is more dependent on ground surface conditions in comparison to basement floors. The heat transfer from basement floors is unaffected by short-term surface conditions, but is closely coupled to conditions in the deep ground below the building. Ground water depth can have a large influence on the heat transfer from buildings, especially buildings with basements. Finally, annual simulations comparing the heat and mass transfer model with a heat conduction model were agreeable if an appropriate value of soil thermal conductivity is chosen.

\section{ACKNOWLEDGMENTS}

The funding for this work from the National Renewable Energy Laboratory and the American Society of Heating, Refrigerating, and Air Conditioning Engineers was greatly appreciated. 


\section{REFERENCES}

[1] Deru, M., and Kirkpatrick, A., 2001, "Ground-Coupled Heat and Moisture Transfer From Buildings: Part 1Analysis and Modeling," ASME Solar Energy Division Conference, Washington, DC.

[2] Deru, M., 2001, "Ground-Coupled Heat and Moisture Transfer From Buildings," Ph.D. Dissertation, Colorado State University, Fort Collins, CO.

[3] Lachenbruch, A. H., 1957, "Three-Dimensional Heat Conduction in Permafrost Beneath Heated Buildings," Geological Survey Bulletin 1052-B.

[4] Muncey, R. W. R., and Spencer, J. W., 1978, "Heat Flow into the Ground Under a House," Energy Conservation in Heating, Cooling, and Ventilating Buildings, Vol. 2, Hoogendoorn, C. J., and Afgan, N. H., Ed.'s, Hemisphere Publishing Corp., Washington, pp. 649-660.

[5] Shen, L. S. and Ramsey, J. W., 1983, "A Simplified Thermal Analysis of Earth-Sheltered Buildings Using a Fourier-Series Boudary Method," ASHRAE Transactions, Vol. 89(1B), pp. 438-448.

[6] Delsante, A. E. and A. N. Stokes, 1983, "Application of Fourier Transforms to Periodic Heat Flow into the Ground Under the Building," Int. J. Heat Mass Transfer, Vol. 26, No. 1, pp. 121-132.

[7] Claesson, J. and Hagentoft, C-E.,1991, "Heat Loss to the Ground From a Building - I. General Theory", Building and Environment, Vol. 26, No. 2, pp. 195-208.

[8] Krarti, M., Claridge, D. E. and Kreider, J. F., 1988a, "The ITPE Technique Applied to Steady-State GroundCoupling Problems," International Journal of Heat Mass Transfer, Vol. 31, No. 9, pp. 1885-1898.

[9] Krarti, M., Claridge, D. E. and Kreider, J. F., 1988b, "ITPE Technique Applications to Time-Varying Two-Dimensional Ground-Coupling Problems," International Journal of Heat Mass Transfer, Vol. 31, No. 9, pp. 1899-1911.

[10] Krarti, M., Claridge, D. E. and Kreider, J. F., 1990, "ITPE Technique Applications to Time-Varying ThreeDimensional Ground-Coupling Problems," Journal of Heat Transfer, ASME, November 1990, Vol. 112, pp. 849-856.

[11] Mitalas, G. P., 1982, "Basement Heat Loss Studies at DBR/NRC," National Research Council of Canada Division of Building Research, DBR Paper No. 1045.

[12] Mitalas, G. P., 1987, "Calculation of Below-Grade Residential Heat Loss: Low-Rise Residential Building," ASHRAE Transactions, Vol. 93(1), pp. 743-784.
[13] Shen, L. S., 1986, "An Invesitgation of Transient, TwoDimensional Coupled Heat and Moisture Flow in Soils," Ph.D. Thesis, University of Minnesota, Minneapolis, Minnesota.

[14] Shen, L. S. and Ramsey, J. W., 1988, “An Investigation of Transient, Two-Dimensional Coupled Heat and Moisture Flow in the Soil Surrounding a Basement Wall," International Journal of Heat and Mass Transfer, Vol. 31, No. 7, pp.1517-1527.

[15]Bahnfleth, W. P., 1989, "Three-Dimensional Modeling of Heat Transfer From Slab Floors," National Technical Information Service, Springfield, VA, ADA210826.

[16] Bahnfleth, W. P., Cogil, C. A., and Yuill, G. K., 1998, "Three-Dimensional Modeling of Conditioned and Unconditioned Basement Thermal Performance," Proceedings of Thermal Performance of the Exterior Envelopes of Buildings VII, Clear Water, Florida, USA, pp. 501-522.

[17] Adjali, M. H., Davies, M., and Littler, J., 1998, "ThreeDimensional Earth-Contact Heat Flows: A comparison of Simulated and Measured Data for a Buried Structure," Renewable Energy, Vol. 15, pp. 356-359.

[18] Moore, R. E., 1939, "Water Conduction From Shallow Water Tables," Hilgardi, Vol. 12, no. 6, pp. 383-426. 


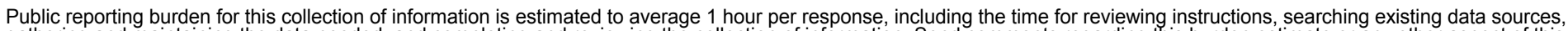

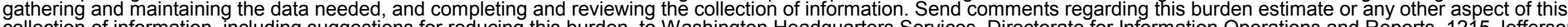
Davis Highway, Suite 1204, Arlington, VA 22202-4302, and to the Office of Management and Budget, Paperwork Reduction Project (0704-0188), Washington, DC 20503.
1. AGENCY USE ONLY (Leave blank)
2. REPORT DATE
February 2001
3. REPORT TYPE AND DATES COVERED Conference Paper

4. TITLE AND SUBTITLE

Ground-Coupled Heat and Moisture Transfer from Buildings; Part 2: Application

5. FUNDING NUMBERS

6. $\mathrm{AUTHOR}(\mathrm{S})$

Michael P. Deru and Allan T. Kirkpatrick

7. PERFORMING ORGANIZATION NAME(S) AND ADDRESS(ES)

National Renewable Energy Laboratory

1617 Cole Blvd.

Golden, CO 80401-3393

9. SPONSORING/MONITORING AGENCY NAME(S) AND ADDRESS(ES)

BET1.4001

8. PERFORMING ORGANIZATION REPORT NUMBER

NREL/CP-550-29694

10. SPONSORING/MONITORING AGENCY REPORT NUMBER

11. SUPPLEMENTARY NOTES

12a. DISTRIBUTION/AVAILABILITY STATEMENT

National Technical Information Service

12b. DISTRIBUTION CODE

U.S. Department of Commerce

5285 Port Royal Road

Springfield, VA 22161

13. ABSTRACT (Maximum 200 words)

In this paper the effects of moisture on the heat transfer from two basic types of building foundations, a slab-on-grade and a basement, are examined. A two-dimensional finite element heat and moisture transfer program is used to show the effects of precipitation, soil type, foundation insulation, water table depth, and freezing on the heat transfer from the building foundation. Comparisons are made with a simple heat conduction model to illustrate the dependency of the soil thermal conductivity on moisture content.

14. SUBJECT TERMS

15. NUMBER OF PAGES

buildings; heat and moisture transfer

16. PRICE CODE

17. SECURITY CLASSIFICATION OF REPORT Unclassified
18. SECURITY CLASSIFICATION OF THIS PAGE Unclassified
19. SECURITY CLASSIFICATION OF ABSTRACT Unclassified
20. LIMITATION OF ABSTRACT

UL 